\title{
Konsep Altmetrics dalam Mengukur Faktor Dampak Artikel Melalui Academic Social Media dan Non-academic Social Media
}

\author{
Asep Haikal Kurniwan \\ Perpustakaan Pasca Sarjana UIN Sunan Kalijaga Yogyakarta \\ email: asephaikal0110@gmail.com
}

\begin{abstract}
Abstrak
Semenjak berkembangkan academic social media dan non-academic social media yang diiringi dengan ledakan informasi telah memicu metode altmetrik dalam mengukur dampak artikel dengan indikantor yang cukup beragam, sehingga pengukur dampak artikel dengan indikator sitasi yang selama ini digunakan telah dilampaui oleh altmetrik. Untuk itu, tulisan ini dimaksudkan untuk mengetahui konsep altmetrics dalam mengukur faktor dampak artikel melalui media sosial yang terbagi menjadi dua bagian academic social media dan non-academic social media. Metode yang digunakan dalam penelitian ini yaitu studi pustaka yang menghimpun berbagai rujukan untuk diolah. Hasilnya menunjukan bahwa altmetrik dengan berbagai tools dalam menangkap data dari berbagai flatform media sosial dapat mengukur dampak dari artikel mulai dari aspek Usage, Captures, Mentioned, Citation, dan Social Media. Secara garis besar altmetrik dengan digerakan oleh mekanisme sistem ini lebih cepat dan cukup kompleks dalam mengungkap dampak artikel, tetapi rawan untuk terjadinya manipulasi data.
\end{abstract}

\author{
Kata kunci : \\ Altmetrik, \\ faktor dampak, \\ Media sosial,
}

\section{A. PENDAHULUAN}

Setiap peneliti atau penerbit sangat senang apabila artikel ilmiah yang diterbitkan memiliki kontribuksi dan mendapatkan dampak (impact) dari berbagai peneliti atau kalangan pada umumnya. Untuk melihat dampak tersebut, sangat dibutuhkan data dan fakta yang kompreheship. Beberapa tools yang digunakan untuk mendapatkan intraksi dari karya ilmiah tersebut bisa dilihat dari Impact Factor, h-index, dan citation analytics. Ketiga pendekatan ini basis analisisnya tidak lepas dari kajian bibliometrika bebasis pada sitasi sebagai objek kajiannya.

Sitasi memang sejak lama menjadi komponen penting dalam melihat dampak dari artikel. Semenjak Gros and Gros dan Eugene Garfield mempopulerkan, pendekatan sitasi ini menjadi sangat populer digunakan oleh berbagai publisher (Pattah, 2013). Bahkan dengan mengunakan objek sitasi sebagai bahan analisis dapat memberikan implikasi praktis dalam kebijakan publisher ataupun peneliti untuk mengembangan ilmu pengetahuan selanjutnya (De Bellis, 2009).

Seiringan dengan ledakan informasi maupun artikel ilmiah yang terbuka untuk diakses secara luas (Dutta, 2016). Penggunaan sitasi sebagai objek utama dalam mengukur dampak sangat kurang relevan. Beberapa kalangan menilai disaat teknologi informasi berkembang saat ini, perlu untuk mempertimbangkan besaran akses, interkasi karya ilmiah secara lengkap, dan sosial media patut dipertimbangkan dalam melihat interaksi dari karya ilmiah (Prasetyawan, 2018). Oleh sebab itu, beberapa kalangan mengusulkan untuk setiap penerbit ataupun peneliti untuk mengunakan pendekatan lain seperti altmetrik. Dimana pendekatan ini dapat melihat dampak dari artikel ilmiah tidak hanya berbasis pada sitasi, melainkan memunculkan data secara lebih luas(Starbuck, 2017).

Altmetrik dapat mendeteksi seberapa banyak artikel atau jurnal ilmiah di bahas atau terpapar 
oleh keluaran artikel ilmiah sejenis dengan banyak indikantor-indikator penilaian. Ciri khas dari almetrik dalam menangkap dampak artikel terbagi menjadi dua yaitu academic social media dan non-academic social media dari pendekatan metrik lainya (Roemer 2015). Dengan indikator ini bukan tidak mungkin di masa mendatang penggunaan altmetrics dengan melihat interaksi dan dampak jurnal ilmiah akan menjadi penting untuk memberikan potensi dalam memprediksi dan merekomendasikan untuk melakukan penelitian (Galligan, 2013).

Dengan melihat perkembangan dalam mengukur dampak artikel ilmiah ini, tulisan ini dimaksudkan untuk mengetahui konsep altmetriks dalam pengukuran Impact faktor dari artikel dengan indikator academic social media dan non-academic social media. Harapanya ketika nanti altmetriks telah berkembang setidaknya sebagai partisipan di bidang informasi seperti pustakawan dapat pertimbangan dalam mengadopsi dan memanfaatkannya.

\section{B. KAJIAN TEORITIS Impact Faktor}

Sebelum membahas mengenai dampak dari jurnal ilmiah, perlu dipahami secara historis artikel ilmiah merupakan sarana utama dalam komunikasi ilmiah. Isitilah komunikasi ilmiah itu sendiri sebagai bentuk hubungan antara dua orang atau lebih dalam bentuk dialog keilmuan (Rowland, 2002). Publikasi dalam artikel ilmiah sebagai jalur formal yang telah disepakati oleh banyak ilmuwan.

Artikel yang menjadi salah satu sarana komunikasi ilmiah perlu dilakukan proses peer-review. Upaya ini dilakukan untukmengevaluasi dan memvalidasi dalam memastikan kualitas riset. Melalui peer review, jurnal ilmiah dinilai untuk melihat apakah topik-topik penelitian tersebut memiliki kebaruan. Dengan mengedepankan hal tersebut bukan tidak mungkin publikasi jurnal ilmiah dapat banyak disitasi dan didiskusikan oleh peneliti lainnya (impact factor).

Impact factor merupakan sebuah faktor dampak dari artikel dengan dilihat dari sitasinya. Semakin sering artikel atau secara keseluruhan jurnal tersebut disitasi oleh artikel lain, maka semakin tinggi level dampak dari artikel tersebut. Biasanya pengukuranya dengan membatasi tahun tertentu saja, kemudian di ukur frekuensi artikel rata-rata dalam jurnal telah disitasi. Tujuan utama dari penghitungan ini untuk mengevaluasi artikel penelitian dan bahkan ditingkat lembaga evaluasi digunakan untuk memutuskan untuk berlangganan terhadap penerbit jurnal (McKiernan, 2019, p.1). sedangkan ditingkan penerbit biasanya digunakan untuk kebijakan perencanaan dalam menyaring artikel-artikel yang akan diterbitkan (Larivière, 2019, p.3).

Dengan adanya dorongan teknologi infomasi dan komunikasi yang semakin matang dalam memfasilitasi berbagai bidang kehidupan. Menurut Lapinski (2013) banyak para peneliti saat ini mengunakan media sosial untuk membahas, merekomendasikan, mengeksplorasi ide-ide, dan mengumpulkan informasi penelitian. Ditambah dengan para peneliti saat ini membagikan informasi bibliografi di bidang yang diminati dengan menggunakan alat manajemen referensi berbasis web. Altmetrik sebagai alat ataupun pendekatan baru dalam menghitung dampak dari sebuah artikel patut diperhitungkan untuk mengukur dampak.

\section{Altmetrics}

Perkembangan dalam mengukur interaksi karya ilmiah dengan menggunakan metrik dan statistik tidak dapat lepas dari dari keilmuan informetrika yang sejak lama telah dikembangkan (Björneborn, 2004). Altmetrik yang mengukur interaksi mengunakan statistik sebagai pendekatannya dapat di katakan bagian dari keilmuan informetrika. Spesifikasi yang khas dari 
altmetrik sendiri yaitu memasukan aspek media sosial, dimana pada metriks tradisional seperti bibliometrik tidak memperhitungkan. Altmetrik singkatan dari alternatif metrik (alternative metrics) yang digagas pada tahun 2010 dan berkembang pada tahun 2011 oleh Jason Priem sebagai cara alternatif untuk mengukur dampak dengan memperluas cakupan (Dhiman, 2015).

Kemunculan alternatif ini sendiri merupakan fenomena dari perkembangan teknologi informasi dan sosial media pada pertengahan 2000-an. Kemajuan dari altmetrik dapat dilihat pada sembilan tahun belakangan telah menjadi bagian dalam mengukur interaksi interaksi berbagai karya ilmiah maupun non-karya ilmiah. Almetriks tumbuh untuk mengambil bagian untuk mengukur dengan melihat ke berbagai flatform media sosial. Dimana bagian dari almetrik ini tidak menjadi bagian pengukuran bibliometrik dalam menilai karya ilmiah yang diskusikan dalam flatform sosial (Roemer, 2015).

Bibliometrik dalam menilai Impact factor dari jurnal (Journal Impact Factor), cenderung bersandar pada sitasi artikel jurnal lainnya. Sedangkan altmetrik dengan memasukan unsur berapa kali karya tersebut dilihat, diunduh, disukai, dihimpun dalam alat sitasi otomatis, dan lain sebagainya (Williams, 2017a). Secara otomatis altmetrik memang telah lebih depan dari Bibliometrik dalam menghitung Impact factor dari jurnal. Bahkan hal ini menjadi solusi untuk berbagai publisher untuk melihat dampak dari jurnal-jurnal yang telah diterbitkan dengan lebih cepat.

Penyaringan data yang dilakukan altmetrik yang mengunakan media sosial terbagi menjadi dua bagian yaitu academic social media dan non-academic social media. Pertama academic social media seperti Repository intitusi, CiteULike, Mendeley, Academia.edu, ResearchGate. Golongan kedua non-academicsosialmedia sepertiFacebook, Twetter,
Youtube, Amazon, Goodread, SlideShare, dan Github (Roemer, 2015).

\section{Tools Pengukuran Altmentrik}

Tools altmetrik dikerjakan oleh mekanisme sistem yang menangkap data dampak dari jurnal ilmiah dari berbagai interaksi diberbagai web sosial. Semua alat ini dikumpulkan dan dianalisis oleh mekanisme sebuah sistem yang diciptakan secara otomatis menangkap berbagai aktivitas karya ilmiah diberbagai web sosial. Adapun beberapa alat yang digunakan baik berbayar maupun open sources sebagai berikut.

\section{Plum Analytics}

Plum Analytics merupakan alat berbasis web yang didirikan pada tahun 2012. Plum Analytics melalui PlumX menyediakan data tentang penggunaan dan dampak penelitian dan produk-produk ilmiah. Sumber data PlumX mencakup lingkungan dan aktivitas online yang terkait dengan penelitian dan khalayak umum, memfasilitasi penemuan tentang bagaimana suatu penelitian atau temuan penelitian secara informal dan secara formal dibahas dalam lingkaran publik dan ilmiah. Contoh sumber termasuk Mendeley, Github, PLOS, Scopus, Web of Science, Delicious, Reddit, Goodreads, Topsy, CrossRef, dan Facebook (Champieux, 2015).

\section{ImpactStory}

Impactstory yang sebelumnya dikenal sebagai Total-Impact dirancang untuk digunakan oleh para peneliti ini secara individual dengan menyusun dan mengontektualisasikan output ilmiah peneliti dalam halaman profil Impactstory orang tersebut. ImpactStory menghubungakan ke beberapa data source seperti SlideShare, ORCID, Scopus, dan lain sebagainya. Impactstory ini kemudian akan menampilkan 
seberapa sering karya ilmiah tersebut dibahas, disimpan, dan dilihat (Roemer, 2015).

\section{Almetrics}

Altmetrics (altmetric.com) merupakan dirancang untuk menghasilkan altmetrik untuk artikel jurnal tunggal ke alat yang merangkum dan membandingkan altmetrik pada tingkat kelembagaan. Dengan demikian hasilnya akan menunjukan dampak rata-rata dari per-jurnal sekali terbit. perangkat berkerja dengan menghitung dan memvisualisasikan perhitungan angka dampak pengaruh publikasi karya ilmiah terhadap sosial media. Terdapat beberapa produk altmetric.com yaitu altmetric badges, altmetric badges for books, altmetric API, altmetric Bookmarlet, Altmetric for publisher, dan altmetric for institutions (Roemer 2015).

\section{PLOS}

PLOS singkatan dari Public Library of Science merupakan sebuah perusahaan publikasi ilmiah yang dapat diakses secara gratis. PLOS meluncurkan alat ukur yang diberinama PLOS ALM, yang dipicu oleh berbagai media sosial bermunculan dan terus berkembang. Alat yang diluncurkan ini dapat digunakan secara gratis untuk melihat interaksi jurnal ilmiah ( https://www.plos.org/).

\section{Kudos}

Kudos (https://growkudos.com) merupakan bagian dari altmetrik yang paling baru. Secara umum tujuan dari kudos ini untuk meningkatkan visibilitas, jangkauan, dan dampak artikel atau jurnal yang diterbitkan. Untuk mengetahui dampak dari artikel, kudos menampilkan berapa kali dilihat, diklik, dibagikan, dan lain sebagainya (Williams, 2017b).

\section{METODE PENELITIAN}

Penelitian ini dilakukan menggunakan studi kepustakaan, di mana studi pustaka merupakan sebuah penelitian yang hanya menggambarkan keadaan dengan menghimpun rujukan-rujukan yang relevan dan diolah untuk tampilkan kepada pembaca (Zed, 2004). Langkah-langkah yang dilakukan yaitu mengumpulkan, memadukan, dan menganlisis rujukan-rujukan seperti buku, artikel-artikel ilmiah, proseding dan lain sebagainya.

\section{HASIL DAN PEMBAHASAN}

\section{Academic Social Media dan non-Academic Social} Media

Semua media sosial saat ini berkembang tidak dapat dilepaskan dari perkembangan teknologi informasi yang semakin gencar dikembangkan untuk melampaui batas-batasan sebelummya. Salah satunya sarana komunikasi yang tumbuh berbagai platform jejaring sosial yang pada akhirnya merubah cara untuk beriteraksi. Sebelumnya setiap individual dibatasi oleh ruang dan waktu untuk terhubungan telah mendapatkan solusi yang tampak nyata untuk menembuh batas-batas tersebut.

Perkembangan dari media sosial, kemudian dalam ruang akademik banyak alat yang digunakan oleh para para akademisi untuk berkomunikasi dan berkolaborasi dengan akademisi dalam mendukung kegiatan ilmiah mereka. secara garis besar flatfom yang digunakan oleh akademisi dapat digolongkan menjadi dua bagian yaitu Academic Social Media dan non-Academic Social Media.

Academic Social Media merupakan media sosial yang diperuntunkan untuk para akademisi secara individu untuk terhubung dengan rekan dan kolega, mencari informasi baru dan menyebarluaskan ide-ide baru kepada masyarakat luas. Secara fungsi dan kegunaanya Academic Social 
Media diperuntukan untuk para akademisi baik itu peneliti, dosen, maupun mahasiswa. Sedangkan non-Academic Social Media merupakan sebuah flatform yang diperuntukan untuk masyarakat luas tanpa miliki karaterstik khusus. Memang flatform tersebut peruntukan untuk semua individu untuk terhubung dengan berbagai masyarakat secara umum (Prasetyawan, 2018).

Manfaat dari flatform ini sendiri yaitu 1) untuk membantu para sarjana menemukan dan membangun koneksi baru, 2) memperkuat dan memelihara koneksi yang ada, 3) untuk up to date dengan penelitian terbaru di komunitas riset mereka (Gruzd, 2012). Manfaat lain dari flatform media sosial yaitu dapat memberikan cara mudah untuk membuat merek atau identitas pribadi para akademisi atau ilmuan untuk mempromosikan diri melalui karya-karya yang telah diterbitkan (Ollier-Malaterre, 2013).

\section{Altmetrik Sebagai Pengukuran Impact Faktor}

Perkembangan Altmetrik menjadi salah satu tools untuk mengukur Impact Factor di pincu oleh ledakan informasi yang memicu berbagai publisher atau secara individu secara terbuka saling bertukar informasi yang terhubung dengan jaringan internet. Adanya ledakan informasi ini menjadikan sangat mungkin jurnal yang telah diterbitkan oleh berbagai pubshier mendapatkan tanggapan dari berbagai kalangan melalui media sosial.

Kemungkinan inilah, altmetriks dikembangkan untuk mengevaluasi berbagai dampak sosial yang tidak dapat dapat dilakukan oleh metode evaluasi berbasis bibliometrik khususnya sitasi. Dalam kasus pengukuran impact faktor, altmetrik bukan menggantikan pendeketan bibliometirik berbasis sitasi, melainkan hanya melengkapi atau melampau kajian tersebut. Pendekatan bibliometrik bebasis sitasi hanya mengukur frekuensi rata-rata artikel yang dikutip di jurnal tahun tertentu. Sedangkan dengan altmetriks akan dapat memberikan impact faktor tidak hanya rata-rata artikel dikutip akan tetapi lebih banyak lagi indikator seperti di baca atau akses, didiskusikan berbagai flatfom media sosial.

Pendekatan bibliometrik dan altmetrik ini secara proposional dapat digunakan berbagai pubshier untuk mengevaluasi impact faktor dari jurnal dan menjadikan hasil diambil sebagai kebijakan dalam mendukung pengembangan penelitian lebih lanjut (Cho, 2017 p.49). Altmetrik mencoba untuk menangkap impactfaktor dari jurnal dengan menghimpun dari berbagai flatform media sosial yang tersebar. Secara garis besar flatform tersebut dibagi menjadi dua yaitu academic social media dan non-academic social media. Menurut Williams (2019) terdapat lima katagori yang ditangkap oleh altmetrik dalam mengukur metrik dampak dari sebuh artikel yaitu salah satu aplikasi altmetriks "plumx" yang secara garis besar cukup lengkap dalam mengukur metrik sebagai berikut.

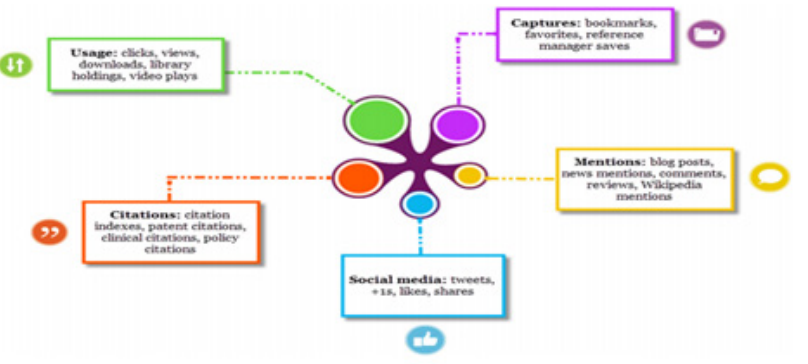

Gambar 1. Lima dimensi data altmetrik dari PlumX (Sumber: Williams, 2019)

Keterangan Gambar:

1. Usage: Indikator yang dihimpun oleh altmetrik disini berupa beberapa kali diklik, dilihat, ditandai dan diunduh oleh pengguna.

2. Captures: Indikator ini menyediakan informasi yang telah menyelamatkan file, termasuk bookmark, garpu kode, favorit, pembaca dan pengamat.

3. Mentioned: Sebutkan data yang mengukur 
bagaimana data dari suatu artikel didiskusi dalam artikel ilmiah maupun dalam tulisan populer seperti posting blog, komentar, ulasan, entri Wikipedia, dan media berita.

4. Social media: Data media sosial mengukur tweet, suka Facebook, dan referensi media sosial untuk file tersebut.

5. Citation: Data sitasi termasuk jumlah sitasi dari indeks sitasi tradisional seperti Scopus dan juga memberikan indikasi dampak masyarakat, termasuk indeks sitasi, sitasi paten, sitasi klinis dan sitasi kebijakan.

Berdasarkan kelima katagori inilah, tools altmetrik bekerja secara otomatis untuk mengukur dampak artikel. Semua data baik dari academic social media dan non-academic social media akan ditampilkan kekuatan metriknya secara detail. Dengan lima katagori diatas juga, altmetrik dalam mengukur dampak artikel akan secara komprehesip menampilkan data-data dari berbagai flatfom sosial media.

Kelebihan altmetrik dalam mengukur dampak artikel, pertama altmetriks dapat mendektesi dampak publikasi yang bukan ilmiah dari beberapa macam seperti database, ditampilkan, komentar, unduh, dan penyebaran dimedia sosial sebagai pendukung data untuk melihat dampak yang lebih jauh. Kedua memungkinkan peneliti untuk untuk lebih cepat ketibambang menggunakan indikator sitasi dalam melihat dampak artikel. Ketiga, melalui altmetrik dalam mengukur dampak dapat memberikan gambaran kepada peneliti untuk mengeksplorasi ide-ide yang menarik untuk dikembangkan dalam sebuah penelitian (Dhiman, 2015).

Kurang relevan juga apabila tidak melihat sisi kelemahan dari altmetrik sebagai metode yang sangat baru ketimbang dengan sitasi dalam mengukur dampak. Adapun kelemahan dari altmetrik ini sendiri yaitu pertama, jejaring sosial rawan terjadinya manipulasi data untuk kepentingan tertentu. Kedua bisa jadi URL yang dishare hanya disukai di media sosial dilakukan oknum yang sengaja untuk menaikan metrik dampaknya (Dhiman, 2015).

\section{E. PENUTUP \\ Simpulan}

Faktor dampak dari sebuah artikel sejatinya memang penting bagi peneliti maupun bagi penerbit untuk mengambil langkah-langkah yang tepat dimasa yang akan mendatang dalam mengembangkan penelitian lanjutan. Altmetrik mungkin menjadi salah satu alternatif untuk mengungkap dampak artikel yang lebih komprehesip ketimbang dengan kajian bibliometrik dengan indikator sitasi. Walaupun Indikator sitasi dalam melihat dampak artikel membutuhkan waktu lama dan memiliki keterbatasan lain dalam mengungkap faktor dampak.

Secara garis besar altmetrik megungkap dampak artikel melalui 2 indikator yaitu academic social media dan non-academic social media. Dimana kedua indikator tersebut yang membedakan hanya kegunaan dan fungsinya. Dalam menangkap data altmetrik dijalankan oleh beberapa tools seperti Almetrics, Plum Analytics, ImpactStory, dan PLOS, Kudos. Melalui tools ini secara garis besar, altmetrik dapat menangkap dampak artikel mulai dari Usage, Citation, Captures Mentioned, dan Social media.

\section{Daftar Pustaka}

Björneborn, L., \& Ingwersen, P. (2004). Toward a basic framework for webometrics. Journal of the American Society for Information Science and Technology, 55, 1216-1227.

Champieux, R. (2015). PlumX. Journal of the Medical Library Association, 103(1), 63-64.

Cho, J. (2017). A comparative study of the impact of Korean research articles in four academic fields using altmetrics. Performance Measurement 
and Metrics, 18(1), 38-51. https://doi. org/10.1108/PMM-02-2016-0005

Dhiman, A. K. (2015). Bibliometrics to Altmetrics: Changing Trends in Assessing Research Impact. DESIDOC Journal of Library \& Information Technology, 35(4), 310-315.

Dutta, B. (2016). Altmetric Manifesto Completes Five Years (2010-2015). Current Science, 110(1), 17.

Galligan, F. \& Dyas-Correia, S. (2013). Altmetrics: Rethinking the Way We Measure. Serials Review, 39(1), 56-61.

Gruzd, A. (2012). 2-Non-academic and academic social networking sites for online scholarly communities. In D. R. Neal (Ed.), Social Media for Academics (pp. 21-37). https://doi. org/10.1016/B978-1-84334-681-4.50002-5

Larivière, V., \& Sugimoto, C. R. (2019). The Journal Impact Factor: A Brief History, Critique, and Discussion of Adverse Effects. In W. Glänzel, H. F. Moed, U. Schmoch, \& M. Thelwall (Eds.), Springer Handbook of Science and Technology Indicators (pp. 3-24). https://doi. org/10.1007/978-3-030-02511-3_1

McKiernan, E. C., Schimanski, L. A., Muñoz Nieves, C., Matthias, L., Niles, M. T., \& Alperin, J. P. (2019). Use of the Journal Impact Factor in academic review, promotion, and tenure evaluations [Preprint]. https://doi.org/10.7287/peerj. preprints.27638v2

Ollier-Malaterre, A., Rothbard, N. P., \& Berg, J. M. (2013). When worlds collide in cyberspace: how boundary work in online social networks impacts professional relationships. The Academy of Management Review, 38(4), 645-669.

Pattah, S.H. (2013). Pemanfaatan kajian bibliometrika sebagai metode evaluasi dan kajian dalam ilmu perpustakaan dan informasi. Khizanah Al-Hikmah 1(1), 11.

Prasetyawan, Y. Y. (2018). Altmetrik sebuah Pengukuran Alternatif untuk Level Dampak dan Desiminasi Publikasi IImiah: Studi Kasus
Mendeley. Anuva: Jurnal Kajian Budaya, Perpustakaan, dan Informasi, 2(1), 1-9. https:// doi.org/10.14710/anuva.2.1.1-9

Roemer, R. C. \& Borchardt, R. (2015). Altmetrics. Chicago: Library Technology Reports.

Rowland. F. (2002). The peer-review process. Learned Publishing, 15(4).

Starbuck, E., \& Purtee, S. (2017). Altmetric scores: Short-term popularity or long-term scientific importance. Digital Library Perspectives, 33(4), 314-323. https://doi. org/10.1108/DLP-01-2017-0005

Track Impact with ALMs | PLOS. (n.d.). Retrieved December 18, 2019, from https://www. plos.org/article-level-metrics

Williams, A. E. (2017a). Altmetrics: An overview and evaluation. Online Information Review, 41(3), 311-317. https://doi.org/10.1108/ OIR-10-2016-0294

Williams, A. E. (2017b). Kudos: Bringing your publications to life? Information and Learning Science, 118(3/4), 114-119. https://doi.org/10.1108/ILS-01-2017-0005

Williams, A. E. (2019). Exploring the utility of an emerging altmetric platform: A SWOT analysis of Plum Analytics. Digital Library Perspectives, 35(3/4), 193-204. https://doi. org/10.1108/DLP-08-2019-0031

Zed, M. (2004). Metode penelitian kepustakaan. Jakarta: Yayasan Obor Indonesia. 